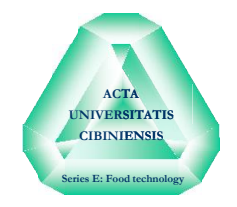

\title{
ANIMAL CARCASS PRICING GRID. EVIDENCES FROM THE ROMANIAN PIGMEAT MARKET
}

\author{
Roxana SAVESCU*1, Georg PLOETZ** \\ *Lucian Blaga University from Sibiu, Romania \\ **University of Applied Sciences, Kufstein, Austria
}

\begin{abstract}
Until the introduction of SEUROP system, price negotiation between pig producers and slaughterhouses was based on two subjective criteria: animal weight and visual inspection of the quality of pigs. To ensure producers a fair payment, European Union created the possibility of binding the price on two objective factors: carcass weight and carcass composition. This paper describes the pricing mechanism developed by Romania in order to respond to European Union requirements for ensuring a fair payment to pig producers. It raises the attention on the difficulties encountered by the producers in understanding the way the commercial value of a pig carcass is calculated in case the selling price is negotiated on a flat rate basis or on a lean content basis (per $\mathrm{kg}$ of carcass weight or per kg of live weight).
\end{abstract}

Keywords: Quality, prices, grading, SEUROP, pig carcass classification.

\section{INTRODUCTION}

In accordance with Council Regulation (EEC) 3220/1984, starting 1 January 1985, pig carcass classification activity (SEUROP) became mandatory in all European Union (EU) member states. Nowadays, EU slaughterhouses are required to weigh the pigs and to divide the carcasses into quality classes according to their estimated lean-meat content.

The purpose of SEUROP carcass classification system is to determine producers to meet the growing consumers' preferences for high content lean meat. This objective can be achieved by developing:

- domestic pricing systems to adequacy remunerate the producers,

- national mechanisms to ensure market transparency and

- EU intervention mechanisms on the pig-meat market when this suffers high price fluctuations.

\footnotetext{
${ }^{1}$ Correponding author. Mailing adress: University Lucian Blaga of Sibiu, Faculty of Engineering, Str. Emil Cioran, No.4, Sibiu, Romania. E-mail: roxana.savescu@ulbsibiu.ro.
} 
The EU system of grading pig carcasses was introduced in Romania with effect from 1 March 2006, under Government Decision 267/2004. Since then, classification activity has been implemented as a compulsory activity in all slaughterhouses and it must be performed for all commercial pigs, for carcasses within the weight range of $50-120 \mathrm{~kg}$, except those coming from pigs that have been used for breeding. The lean meat is content assessed with two optical probes, OptiGrade PRO and Feat'o'Meater. In a few cases, the ruler based Zwei-Punkte method is used. Carcasses must be presented according to some standards stipulated in the legislation. Back fat thickness and muscle depth are measured, at a point $7 \mathrm{~cm}$ left from the edge of the split back, at the level of the 3/4 last rib. Lean meat percentage in the carcass is then estimated based on prediction equations and assessment methods approved by European Commission in 2008. The carcasses are then graded in one of the six quality classes of the SEUROP system as presented in Table 1. The entire process must be performed by qualified people.

Table 1. EU scales for grading pig carcasses (Regulation (EU) 1308/2013)

\begin{tabular}{|c|l|}
\hline Class & Lean meat as percentage of carcass weight $\mathbf{( \% )}$ \\
\hline S & 60 or more \\
\hline E & 55 or more but less than 60 \\
\hline $\mathbf{U}$ & 50 or more but less than 55 \\
\hline $\mathbf{R}$ & 45 or more but less than 50 \\
\hline O & 40 or more but less than 45 \\
\hline P & less than 40 \\
\hline
\end{tabular}

Every week, the classification agents (agencies or independent classifiers) must send the results of the classification activity to Carcass Classification Commission (CCC). Using the quotations recorded for $\mathrm{E}$ and $\mathrm{S}$ grade carcasses weighing between $60 \mathrm{~kg}$ and $120 \mathrm{~kg}, \mathrm{CCC}$ determines the national market price. The market price is expressed in RON/100 kg cold carcass and is weekly notified to the European Commission, Agriculture Directorate, as shown in Figure 1. By the end of the classification process, the producer must be provided with a statement containing information like: pigs batch identification number, carcass number, carcass weight, estimated percentage lean meat content and total price paid for each pig and for the whole batch of pigs.

The aim of this paper is to describe the pricing grid mechanism developed by Romania in order to respond to EU requirements for ensuring a fair payment to producers and obtain market transparency. 


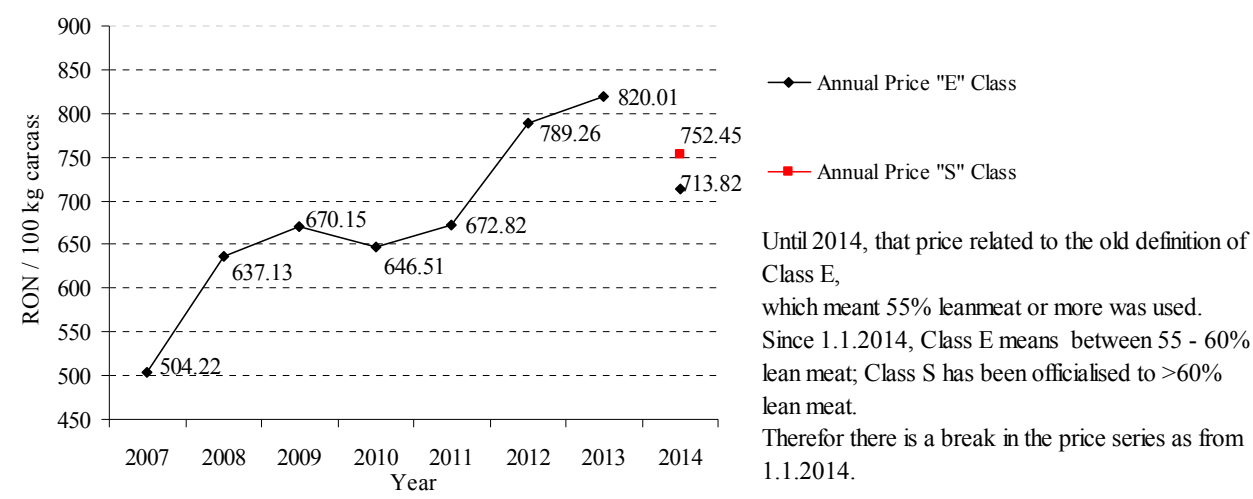

Figure 1. Market price evolution for carcasses from E and S class from Romania between 2007 and 2014. (Carcass Classification Commission)

\section{MATERIALS AND METHODS}

The research methodology applied in this study consisted in:

- Reviewing the normative acts regulating pig carcass classification activity in EU Romania and the rules for applying the pig carcass grading scheme;

- Investigating secondary data available in different scientific studies or reports issued by professional organizations;

- Discussions with the representatives of the Romanian Carcass Classification Commission (CCC) and Association of Classification Agencies, in order to get a clear picture on pricing practices;

- Conducting simulations in SIGRAC, the management information system used by Romanian classification agencies to register and report the results of the classification activity performed in slaughterhouses.

\section{RESULTS}

Romanian technical classification norms for pig carcases (Ministerul Agriculturii si Dezvoltării Rurale, Ordinul Nr. 839/2014) stipulate the obligation of all slaughterhouses that classify pigs to apply the lean meat pricing grid when calculating the total value that has to be paid to a producer for the batch of pigs he delivered (Table 2).

A base price is set for a carcass with a lean meat content of $56 \%$ (reference level). Depending on the real lean meat content of the carcass established after the classification, the base-price is then adjusted: it gets a bonus in case the carcass has higher lean meat content than $56 \%$, or a penalty in case it is lower than $56 \%$. 
Table 2. Lean meat pricing grid applied to all commercial pigs classified (Ministerul Agriculturii si Dezvoltarii Rurale, Ordinul Nr. 839/2014)

\begin{tabular}{|c|c|c|}
\hline Lean meat percentage & $\begin{array}{c}\text { Bonus / } \\
\text { Penalty }\end{array}$ & $\begin{array}{c}\text { Accumulated bonus / } \\
\text { Accumulated penalty }\end{array}$ \\
\hline$>=64 \%$ & $-0,50 \%$ & $8,00 \%$ \\
\hline $63 \%$ & $0,00 \%$ & $8,50 \%$ \\
\hline $62 \%$ & $0,00 \%$ & $8,50 \%$ \\
\hline $61 \%$ & $1,00 \%$ & $8,50 \%$ \\
\hline $60 \%$ & $1,50 \%$ & $7,50 \%$ \\
\hline $59 \%$ & $2,00 \%$ & $6,00 \%$ \\
\hline $58 \%$ & $2,00 \%$ & $4,00 \%$ \\
\hline $57 \%$ & $2,00 \%$ & $2,00 \%$ \\
\hline Reference level 56\% & $\mathbf{0 , 0 0 \%}$ & $\mathbf{0 , 0 0 \%}$ \\
\hline $55 \%$ & $-1,00 \%$ & $-1,00 \%$ \\
\hline $54 \%$ & $-1,00 \%$ & $-2,00 \%$ \\
\hline $53 \%$ & $-2,00 \%$ & $-4,00 \%$ \\
\hline $52 \%$ & $-2,00 \%$ & $-6,00 \%$ \\
\hline $51 \%$ & $-4,00 \%$ & $-10,00 \%$ \\
\hline$<=50 \%$ & $-10,00 \%$ & $-20,00 \%$ \\
\hline
\end{tabular}

Technical classification norms mention the possibility for the slaughterhouse to use, in addition to the national lean meat pricing grid, an own developed carcass weight pricing scale for different carcass weight ranges. The slaughterhouse is required to apply this carcass weight scale uniformly for all suppliers of pigs, throughout the whole calendar year. The lower limits of the carcass weight scale can be: $75 \mathrm{~kg}, 80 \mathrm{~kg}$ or $85 \mathrm{~kg}$ and upper limits can be: 95 $\mathrm{kg}, 100 \mathrm{~kg}, 105 \mathrm{~kg}$ or $120 \mathrm{~kg}$. The carcass weight bonuses/penalties starts with an initial value of $0 \%$ and the other values are obtained by incrementing the initial value by $1 \% /-1 \%$ up to $+10 \% /-10 \%$.

The base price is determined by free negotiation and consensus between the seller (supplier of pigs) and the buyer (slaughterhouse). Depending on market conditions, specific needs of the slaughterhouse or existing unsalable inventory, the base-price may be higher or lower and it may not necessarily be the same for all farmers. There are three possibilities for the seller and the buyer to negotiate the base price, as stipulated in legislation (Ministerul Agriculturii si Dezvoltarii Rurale, Ordinul Nr. 839/2014 and Ordinul Nr. 1972/2015):

- Lean content related price per $\mathrm{kg}$ of carcass weight;

- Lean content related price per kg of live weight;

- Flat rate based price per kg of live weight (a unique price for the entire batch of pigs, related only to the live weight and not to the lean content of the carcass). 
Because of lack of understanding on how the pricing mechanism works, in practice, pigs are rarely assessed for carcass lean content outside of a few larger slaughterhouses and tend to be purchased on a flat rate basis.

Once the base price is negotiated, it must be communicated to the classifier. After slaughtering, weighting, grading and marking the carcasses, the data regarding each animal carcass (carcass weight, back fat thickness and muscle thickness) are inputted into an electronic application called SIGRAC. The total amount to be paid to the producer for his entire batch of pigs is automatically calculated taking into account the classification results and the application of price grid. The grading report is then generated and copies are handed over to the owner of the animals and to the slaughterhouse. Finally, the payment is done on the basis of this classification statement.

It should be mentioned here that both "reference level" and the "pricing grid(s)" are terms not regulated by EU legislation. Each EU member state is free to develop its own pricing grid system. The reference level varies from country to country (eg. in France, the reference level is $56 \%$, in Germany it is $57 \%$, in Romania $56 \%$ - as mentioned by CCC's representative) and sometimes it may vary in each country, from slaughterhouse to slaughterhouse. In Romania, CCC is the only authority entitled to set up and then to annually modify the pricing grid.

In order to understand how the pricing grid mechanism works, we illustrate the calculation of the total amount to be paid by a slaughterhouse to a producer who delivers a batch of 3 pigs with the features shown in Table 3 .

Table 3. Characteristics of a batch of 3 pigs delivered by a producer to a slaughterhouse

\begin{tabular}{|l|r|}
\hline $\begin{array}{l}\text { Total live weight, established at the entrance of the } \\
\text { slaughterhouse, for all pigs }\end{array}$ & $300 \mathrm{~kg}$ \\
\hline $\begin{array}{l}\text { Individual carcass weight, established when the pigs are } \\
\text { classified }\end{array}$ & $\begin{array}{r}\text { Pig \#1:85 kg } \\
\text { Pig \#2: 70 kg } \\
\text { Pig \#3: } 90 \mathrm{~kg}\end{array}$ \\
\hline $\begin{array}{l}\text { Total carcasses weight, for all pigs [sum of individual } \\
\text { carcass weights] }\end{array}$ & $245 \mathrm{~kg}$ \\
\hline $\begin{array}{l}\text { Average weight yield [total carcasses weight / Total live } \\
\text { weight] }\end{array}$ & $81.67 \%$ \\
\hline $\begin{array}{l}\text { Individual live weight established based on the average } \\
\text { weight yield [individual carcass weight / average weight } \\
\text { yield] }\end{array}$ & $\begin{array}{r}\text { Pig \#1: } 104.08 \mathrm{~kg} \\
\text { Pig \#2: } 85.72 \mathrm{~kg} \\
\text { Pig \#3: } 110.20 \mathrm{~kg}\end{array}$ \\
\hline $\begin{array}{l}\text { Lean meat content in each carcass established as a result } \\
\text { of the classification process }\end{array}$ & $\begin{array}{r}\text { Pig \#1: } 57.4 \% \\
\text { Pig \#2: } 53.2 \% \\
\text { Pig \#3:56.2\% }\end{array}$ \\
\hline $\begin{array}{l}\text { Average lean meat content for the entire batch [average } \\
\text { mean of lean meat contents in each carcass] }\end{array}$ & $55.6 \%$ \\
\hline
\end{tabular}


Suppose the producer and the slaughterhouse negotiates a base price of 7 $\mathrm{RON} / \mathrm{kg}$ of carcass weight. Three questions arise:

1. How much money will the producer get for his batch of 3 pigs?

2. In case of negotiations done on $\mathrm{kg}$ of live weight, what is the minimum base price that the farmer must accept so that he is not losing money?

3. In case the negotiations are done on a flat rate, what is the minimum base price that the farmer must accept so that he is not losing money?

The calculations are provided in Table 4.

Table 4. Price calculation for three options (own calculations, SIGRAC simulations)

\begin{tabular}{|c|c|c|c|}
\hline & $\begin{array}{c}\text { Option } 1 \\
\text { lean content related } \\
\text { price per kg of } \\
\text { carcass weight }\end{array}$ & $\begin{array}{c}\text { Option 2 } \\
\text { lean content } \\
\text { related price per } \\
\text { kg of live weight }\end{array}$ & $\begin{array}{c}\text { Option 3 } \\
\text { flat rate base-price } \\
\text { per kg of live } \\
\text { weight }\end{array}$ \\
\hline $\begin{array}{l}\text { Base price } \\
\text { negotiated: }\end{array}$ & 7 RON/kg carcass & $5,72 \mathrm{RON} / \mathrm{kg}$ live & $5,69 \mathrm{RON} / \mathrm{kg}$ live \\
\hline $\begin{array}{l}\text { Price from } \\
\text { pricing grid } \\
\text { Pig \#1 (+2\%): } \\
\text { Pig \#2 }(-4 \%) \text { : } \\
\text { Pig \#3 }(+0 \%) \text { : }\end{array}$ & $\begin{array}{l}7.14 \mathrm{RON} / \mathrm{kg} \text { carcass } \\
6.72 \mathrm{RON} / \mathrm{kg} \text { carcass } \\
7.00 \mathrm{RON} / \mathrm{kg} \text { carcass } \\
\end{array}$ & $\begin{array}{l}5.83 \mathrm{RON} / \mathrm{kg} \text { live } \\
5.49 \mathrm{RON} / \mathrm{kg} \text { live } \\
5.72 \mathrm{RON} / \mathrm{kg} \text { live }\end{array}$ & $\begin{array}{l}5.69 \mathrm{RON} / \mathrm{kg} \text { live } \\
5.69 \mathrm{RON} / \mathrm{kg} \text { live } \\
5.69 \mathrm{RON} / \mathrm{kg} \text { live }\end{array}$ \\
\hline $\begin{array}{l}\text { Total amount } \\
\text { to be paid to } \\
\text { the producer, } \\
\text { out of: }\end{array}$ & $\underline{1,707.30 \mathrm{RON}}$ & $\underline{1,707.73 \mathrm{RON}}$ & $\underline{1,707.00 \mathrm{RON}}$ \\
\hline Pig \#1: & $\begin{array}{c}\text { 606.90 RON } \\
{[85 \mathrm{~kg} *} \\
7.14 \mathrm{RON} / \mathrm{kg}]\end{array}$ & $\begin{array}{c}\text { 606.79 RON } \\
{[104.08 \mathrm{~kg} *} \\
5.83 \mathrm{RON} / \mathrm{kg}]\end{array}$ & $\begin{array}{c}\text { 592.22 RON } \\
{[104.08 \mathrm{~kg} *} \\
5.69 \mathrm{RON} / \mathrm{kg}]\end{array}$ \\
\hline Pig \#2: & $\begin{array}{c}470.40 \mathrm{RON} \\
{[70 \mathrm{~kg} *} \\
6.72 \mathrm{RON} / \mathrm{kg}]\end{array}$ & $\begin{array}{c}\text { 470.60 RON } \\
{[85,72 \mathrm{~kg} * 5.49} \\
\mathrm{RON} / \mathrm{kg}]\end{array}$ & $\begin{array}{c}\text { 487.75 RON } \\
{[85,72 \mathrm{~kg} *} \\
5.69 \mathrm{RON} / \mathrm{kg}]\end{array}$ \\
\hline Pig \#3: & $\begin{array}{c}\text { 630.00 RON } \\
{[90 \mathrm{~kg} *} \\
7.00 \mathrm{RON} / \mathrm{kg}]\end{array}$ & $\begin{array}{c}\text { 630.34 RON } \\
{[110.20 \mathrm{~kg} *} \\
5.72 \mathrm{RON} / \mathrm{kg}]\end{array}$ & $\begin{array}{c}\text { 627.04 RON } \\
{[110.20 \mathrm{~kg} *} \\
5.69 \mathrm{RON} / \mathrm{kg}]\end{array}$ \\
\hline $\begin{array}{l}\text { Average price } \\
\text { per kg live }\end{array}$ & $\begin{array}{c}5.69 \mathrm{RON} / \mathrm{kg} \text { live } \\
{[1,707.30 \mathrm{RON} /} \\
300 \mathrm{~kg}]\end{array}$ & $\begin{array}{c}5.69 \mathrm{RON} / \mathrm{kg} \text { live } \\
{[1,707.73 \mathrm{RON} /} \\
300 \mathrm{~kg}]\end{array}$ & $\begin{array}{c}5.69 \mathrm{RON} / \mathrm{kg} \text { live } \\
{[1,707.00 \mathrm{RON} /} \\
300 \mathrm{~kg}]\end{array}$ \\
\hline $\begin{array}{l}\text { Average price } \\
\text { per kg carcass }\end{array}$ & $\begin{array}{c}6.97 \mathrm{RON} / \mathrm{kg} \\
\text { carcass } \\
{[1,707.30 \mathrm{RON} /} \\
245 \mathrm{~kg}] \\
\end{array}$ & $\begin{array}{c}6.97 \mathrm{RON} / \mathrm{kg} \\
\text { carcass } \\
{[1,707.73 \mathrm{RON} /} \\
245 \mathrm{~kg}] \\
\end{array}$ & $\begin{array}{c}6.97 \mathrm{RON} / \mathrm{kg} \\
\text { carcass } \\
{[1,707.00 \mathrm{RON} /} \\
245 \mathrm{~kg}] \\
\end{array}$ \\
\hline
\end{tabular}


In conclusion, the answers to the three questions are:

1. In case the negotiated base price is $7 \mathrm{RON} / \mathrm{kg}$ of carcass weight, the total amount of money the farmer receives for the 3 pigs is $1,707.30 \mathrm{RON}$.

2. The minimum price the farmer should accept in case the negotiations take place on lean content related price per $\mathrm{kg}$ of live animal is 5.72 $\mathrm{RON} / \mathrm{kg}$ of live weight. (e.g., in case the farmer negotiates a price of 5.60 $\mathrm{RON} / \mathrm{kg}$ of live weight, based on the same principle of calculus as described in Table 4 - Column "Option 2", he will be finally paid with $1,672.59 \mathrm{RON})$

3. The minimum price the farmer should accept in case the negotiations are done on a flat rate per $\mathrm{kg}$ of live animal is $5.69 \mathrm{RON} / \mathrm{kg}$ of live weight. (e.g., in case the farmer negotiates a flat-rate price of $5.60 \mathrm{RON} / \mathrm{kg}$ of live weight, based on the same principle of calculus as described in Table 4 - Column "Option 3", he will be finally paid with 1,680.00 RON)

\section{CONCLUSIONS}

The amount of money a pig supplier receives from slaughterhouse depends on the method of negotiating the price. In the example presented in this paper, in order to get about 1,707.30 RON for a batch of 3 pigs, the supplier must negotiate a price of $7 \mathrm{RON} / \mathrm{kg}$ of carcass weight or a price of $5.72 \mathrm{RON} / \mathrm{kg}$ of live weight or a flat-rate price of $5.69 \mathrm{RON} / \mathrm{kg}$ of live weight. Not knowing the mechanism of prices may cause loss to either party involved in the transaction. Because of the simplicity and financial security, producers prefer the flat-rate system. Pricing mechanism based on carcass quality (price $/ \mathrm{kg}$ of carcass weight) is superior in terms of commercial information provided (individual information differentiated by quality classes).

SEUROP classification system was developed by European Commission as an instrument to fairly respond to the needs of producers, processors and final consumers. Whether it is well understood and appreciated by all pork-meat value chain players, cannot be assessed now and requires further research.

\section{ACKNOWLEDGEMENT}

This work was supported by the strategic grant POSDRU/159/1.5/S/133255, Project ID 133255 (2014), co-financed by the European Social Fund within the Sectorial Operational Program Human Resources Development 2007-2013.

The authors thank Mr. Marian Laba, Romanian Carcass Classification Commission and Mr. Valentin Diaconu, Romanian Carcass Classification Association for valuable information provided for this manuscript. 


\section{REFERENCES}

1. Carcass Classification Commission, Pretul de piata al procilor la intrarea in abator in anul 2014, Retrieved January 20, 2015, from http://ccceurop.ro/rezultate_detalii.php?rezultate_id $=1775$

2. Carcass Classification Commission (2015), Sistemul Informatic de Gestiune a Rezultelor Activităţii de Clasificare SIGRAC [computer software], Romania: agentii de clasificare.

3. Council of the European Communities (1984), Council Regulation (EEC) No. 3220 determining the Community scale for grading pig carcasses, Official Journal L 301, 20/11/1984, p. 0001 - 0003.

4. European Parliament and The Council OF European Union (2013), Regulation (EU) No 1308, establishing a common organization of the markets in agricultural products, Annex IV, B, Official Journal L 347, 20.12.2013, p. 671-854.

5. Guvernul Romaniei (2004), Hotararea de Guvern nr. 267 privind instituirea sistemului de clasificare a carcaselor de porcine, bovine si ovine, Monitorul Oficial nr. 228 din 16.03.2004

6. Ministerul Agriculturii si Dezvoltarii Rurale (2014), Ordinul $n r .839$ pentru aprobarea Normelor tehnice de clasificare a carcaselor de porc, Monitorul Oficial nr. 394 din 28.05.2014.

7. Ministerul Agriculturii si Dezvoltarii Rurale (2014), Ordinul nr. 1972 privind modificarea anexei la Ordinul $n r$. 839/2014 pentru aprobarea Normelor tehnice de clasificare a carcaselor de porci, Monitorul Oficial nr. 15 din 8.01.2015.

8. Rotaru, M., Savescu R., (2014), The European Pig Carcasses Grading System - A Strategic Instrument of Competition, Joint International Conference of Doctoral and Post-Doctoral Researchers, 12-13 September, 2014, University from Craiova, Romania. 